\title{
Den danske deltagelse ved De Olympiske Lege i Athen 1896 Af Vibeke Worm
}

Få kan være i tvivl om, at de moderne olympiske lege havde 100 års fødselsdag i 1996. Uden tvivl ved mange også, at Danmark var repræsenteret ved de første moderne olympiske lege i Athen den 6.-15. april 1896 (25. marts -3. april efter græsk kalender). Danmark har i hele perioden været en særdeles trofast aktør og tilskuer i udviklingen af disse lege. Jeg vil her søge at afdække og samlet beskrive denne første spæde danske start.

\section{Baggrund}

Industrialiseringen bevægede sig omkring århundredeskiftet ind i den modne fase uden at miste sin relative vækst. Landenes indbyrdes del af denne vækst viser, at England havde svært ved at bevare førerstillingen, hvor USA fremviste konstant fremgang på en række nøgleindustrier; Frankrig havde tilbagegang og Tyskland fortsat vækst. Politisk kan perioden i slutningen af det forrige århundrede betegnes som den væbnede fred, hvor stormagterne i Europa indgår, forlænger og nyetablerer alliancer og forbund med og mod hinanden. »Ist Krieg im Sicht? « betegner her kort den sindsstemning, som den almindelige europæer følte, og som Pierre de Coubertin ad pædagogisk og folkelig vej søgte at modvirke ved at finde et mellemfolkeligt middel, der kunne skabe forståelse for fred mellem nationer og folk. ${ }^{1}$ Sport for fred.

I Danmark skete det industrielle gennembrud omkring 1890'erne. ${ }^{2}$ Den mest dynamiske udvikling fandt sted i København med et stærkt voksende indbyggertal, et voksende antal industriarbejdere, tekniske landvindinger og et borgerskab, der forstod at leve med de nye tider. De tekniske landvindinger kunne bl.a. ses på et stigende antal dampskibe, der gjorde udveksling af varer og tjenesteydelser - herunder sportens fremvækst mulig.

\section{Sportens fremkomst}

Enkelte idrætsforskere mener, at det var industriens gennembrud, der karakteriserede legemsøvelsernes gennembrud som sport. Sporten når Danmark med samme tidsforskydning som den industrielle revolution. ${ }^{3}$

I begyndelsen af 1890'erne havde den engelske sport i København et stort omfang. Derfor blev deltagelse i de olympiske lege alene et spørgsmål for hovedstadens sportsudøvere. Gennemlæser man datidens sportstidsskrifter var der ikke meget at berette uden for voldene. Den svenske gymnastik, som jo i overvejende grad var bondesamfundets idræt, var en inkommensurabel aktivitet på den internationale scene og dyrkedes i Danmark uden for voldene. En del af det københavnske borgerskab herunder det nye teknokrati - var orienteret mod Europa.

\section{Olympismen - en ideologi}

Enhver folkelig bevægelse har et tankesæt, som kan begrunde de handlinger, bevægel- 
sen viser sig ved. Den olympiske bevægelse kalder sit sæt af tanker og værdier for olympisme. Olympismen blev tænkt som en bestemt måde at dyrke idræt på, men samtidigt tænkt så alment, at den mentes at have gyldighed på en lang række af livets områder. Olympismen bliver på denne måde en ideologi, hvor idrætten bliver et led i opdragelsen. Det, som sker inden for idrætslivet, kan overføres til andet liv. Fra Grækenlands gyldne klassiske periode tog man menneskesynet om det hele menneske, som ytrede sig i det sande, det skønne og det gode. ${ }^{4}$

\section{Kongressen i Sorbonne 1894.}

Det blev på den internationale Sportskongres - senere nummereret som IOC's første kongres - afholdt i Paris i perioden den 16.-23. juni 1894, at Pierre de Fredy's, baron de Coubertin fra en lille by nær Paris, Coubertin, forslag om en genoplivelse af de olympiske lege vandt gehør.

Mødets formål var primært at få en ordning på amatør- og regelspørgsmålet, idet konkurrencer eks. mellem England og Frankrig stødte på store vanskeligheder, når man skulle afgøre hvem, der fair kunne konkurrere mod hvem og efter hvilke regler. På samme måde som det internationale samfund var ved at udstikke fælles spilleregler, måtte sporten også samordne sit regelsæt. Coubertin benyttede sig af sin stilling i forbundet til som sidste dagsordenpunkt at sætte genoplivelse af de olympiske lege.

\section{Amatфr-og regelspфrgsmålet}

På kontinentet - herunder i Danmark - var professionel sport ikke ukendt. Pengesporten sås i cykelløb, boksning, brydning og fodsport. Sport var et middel til forbedrede $\emptyset$ konomiske levevilkår; men man kunne også tjene penge ved at undervise i idræt. Heroverfor stod det pædagogiske og politiske aspekt, hvor idrætten var midlet til en styrkelse af folkekarakteren. Den danske oplympianer Eugen Stahl Schmidt og senere medstifter af Dansk Idræts-Forbund havde allerede i 1893 søgt at skille skidt fra kanel i artiklen: Hvad forstås ved en professionel? ${ }^{5}$

Idræt var konkurrence, men fair konkurrence, og det var derfor unfair at lade en person, der ofte i sit arbejde kunne træne, matche mod en person, der først kunne træne efter 54-60 timers arbejdsuge fordelt på 6 dage. ${ }^{6}$

Udover amatørspørgsmålet var det manglende regelsæt et problem. Man manglede en national og international idrætsorganisation til at koordinere retningslinier, hvorefter man på tværs af landegrænserne kunne konkurrere. På dansk/ norsk foranledning forsøgte man også midt i 90'erne at lave fælles nordiske regler for at fremme interskandinaviske idrætskampe.

\section{Legenes struktur og organisering}

Kongressen i Sorbonne nedsatte en græsk national komite til organiseringen af legene. Denne måtte efter kort tid meddele, at Grækenland ikke havde ressourcer til afholdelsen. Coubertin rejste derfor i 1895 til Athen for at overtale den græske statsminister til at påtage sig forpligtelsen med legene. Dette lykkedes kun indirekte. Coubertin holdt under besøget et foredrag for 700 mennesker herunder også pressen, og her fik Coubertin tilhørenes opbakning til, at afholdelsen skulle foregå i Athen. Herefter indvilgede statsministeren $\mathrm{i}$, at der måtte 
nedsættes en komite, som skulle sørge for at rejse penge til formålet, men at regeringen ikke magtede at støtte legene $\varnothing$ konomisk. Der blev herefter dannet en national organisationskomite, hvor den græske kronprins blev kransekagefigur. Denne var sønnesøn af den danske kong Chr. IX, »Europas svigerfar«. Faderen hed Vilhelm, der under navnet Georg 1. blev hellenernes konge i 1863 . Kronprinsen hed Konstantin, der efterfulgte faderen efter, at denne myrdedes i Saloniki 1913.

Den hellenske komite var den 13. januar 1895 således en realitet. ${ }^{7}$ Det var den hellenske komites hovedopgave at sørge for afholdelsen og finansieringen af legene. Desuden udgav komiteen $i$ april samme år et skrift indeholdende regler for legene med en definition af, hvad god sportsånd var samt regler for officials. Disse blev trykt på engelsk, tysk, fransk og græsk og derefter udsendt. ${ }^{8}$

\section{Invitationen og dansk deltagelse}

Der deltog 11 lande i de første moderne olympiske lege. 9 fra Europa og med undtagelse af Tyskland alle industrialiserede lande samt 2 oversøiske nationer, som også havde teten $\mathrm{i}$ industriens fremmarch.

Deltagerlandene ved de første moderne olympiske lege var:

Australien, Danmark, England, Frankrig, Grækenland, Schweiz, Sverige, Tyskland, Ungarn, USA og Østrig.

De moderne olympiske lege blev skabt i Europa og var for Europa. Trods den bitre strid mellem den tyske Turnerschaft, der var imod enhver international kontakt især med fransk og engelsk inspireret sport på tysk jord, ses alligevel tysk deltagelse, idet de tyskere, som var tilhængere af den engelske sport, sendte deltagere afsted til legene. ${ }^{9}$

Den 25. november 1895 udsendte den hellenske komite ${ }^{10}$ en invitation om deltagelse til de første moderne olympiske lege.

Invitationen var personlig. I andet afsnit står:

.... at indbyde Dem til at deltage...

Invitationen indledes med et stor M (Monseur.......), hvor der gives plads til at indføre den person, som invitationen skal gælde. Det er således ikke et land, ej heller en organisation, der inviteres. Navnene skulle dog først godkendes af den internationale komite i Paris - givetvis af Coubertin, som generalsekretær i IOC. Den hellenske komite $\varnothing$ nskede svar tilbage. Der eksisterer i fotokopi i Danmark to forskellige invitationer uden påført navn. ${ }^{11}$ De håndskrevne datoer tyder på, at de er forskellige. Den ene er repareret med tape. Men ingen med navn. Originalerne mangler. En personlig invitation mangler - også i kopi. Hvorfor? Ingen ved det, ingen kilde har endnu fortalt, hvilken/hvilke personer i Danmark, der har fået tilsendt invitation fra Grækenland. I DIF's jubilæumsbog Dansk Idræetsliv angives, at Københavns Roklub (KR) fik en invitation. Det er muligt, men næppe sandsynligt, idet KR's forhandlingsprotokol intet siger herom. Det store spørgsmål er stadig, hvem i Danmarks har modtaget den $\mathrm{i}$ begyndelsen af december måned 1895? I dagbladet Politiken anføres, at den græske konsul i Danmark undrede sig over, at ingen i Danmark har reageret positivt på indbydelsen. Dette skyldes i følge journalisten, at ingen i Danmark bortset fra en cykelrytter har fået en invitation. Kommunikationen kunne i det organisationsfattige Danmark vise sig at være et problem. Invitationerne kunne være gået tabt. Den 
græske hellenske komite sendte derpå en række blanke invitationer. Det er mit gæt, at de to nævnte må være fra denne eftersending. I Sverige vides, at Victor Balck som leder af det svenske Gymnastikforbund havde fået en invitation. Han sad jo også som IOC medlem tæt ved.

Den græske kronprins var en af de aktivt ledende i den hellenske komite, og med det nære familiære forhold det græske kongehus havde til Danmark, og de eksperter som Danmark leverede til eks. til de græske stalde (Weizmann) er det ikke utænkeligt, at en invitation indirekte er formidlet gennem en politisk eller forretningsmæssig forbindelse til en dansk idrætsudøver. Det er også muligt, at IOC-medlemmet Victor Balck i Stockholm, der havde nære og stærke forbindelse til det københavnske idrætsliv specifikt Københavns Roklub (KR), som han var æresmedlem af, og som Eugen Stahl Schmidt (Eugen Schmidt) også tilhørte, kan have givet Eugen Schmidt en invitation. Ved gennemgang af KR's arkiv, er der dog intet fundet. Der foreligger i KR's arkiv en invitation til Eugen Schmidt til IOC's anden kongres i Lehavre samt et personligt postkort fra Coubertin sendt i 1897 fra Paris til Eugen Schmidt, men denne kontakt kan være skabt i forbindelse med Athen-legene.

Eugen Schmidt's stilling på Carlsbergbryggerierne var også en mulighed for den erhvervsmæssige kontakt. I en endnu ikke publiceret OL-bibliografi mener forfatteren, at inspektør ved Carlsberg bryggerierne Eugen Schmidt som den person med bredest international kontakt skulle have modtaget invitationen fra den hellenske komite. ${ }^{12}$ Dette mener jeg, kan være tvivlsomt, idet samme inspektør indtil 31.12.1895 også var i redaktionskomiteen af idrætsbladet Idrat, hvor han ville have haft mulighed for at omtale invitationen - muligvis endog, at han havde modtaget den. Idrat - Dansk Sportstidende bringer gennem offentliggørelsen af en brevveksling mellem Clubben Cyclisten (CC) og den meget berømte danske amatørcykelrytter og forpagter af en cykelforretning Christian Ingeman-Petersen, hvori det antydes, at han eller et bestyrelsesmedlem $\mathrm{i}$ klubben har fået en invitation.

Paa Foranledning af Herr. Chr. Ingeman-Petersen skal jeg udtale at den da »Clubben Cyclistens « Bestyrelse havde fattet Beslutning om at søge Danmarks Cyckelsport repræsenteret ved de olympiske Lege i Grækenland i Foraaret 1896, gennem et af Bestyrelsens Medlemmer...

Kbh. 17. Februar 1896 Formand Hald. ${ }^{13}$

Rigtigheden af ordlyden i brevet er bekræftet af flere - herunder Christian Ingeman-Petersen selv. Menigt medlem i CC's bestyrelse, C.H. Bærentzen, anfører i samme kilde, at han privat har spurgt, om Danmarks meget berømte cykelrytter ville repræsentere Clubben Cyclisten.

I CCs forhandlingsprotokol står følgende:

Det vedtoges eventuelt at lade sig repræsentere ved Væddeløbene under de olympiske lege i Grækenland.

Det nævnte Betyrelsesmedlems Henvendelse maa derfor anses som sket privat, men i øvrigt paa min Foranledning som Clubbens Fomand.

\section{Hald \\ 22. Febr. $1896^{14}$}

Samme blad kunne dog allerede i sit første nummer i januar 1896 bringe historien om, at der var en overenskomst mellem Cyclisten (CC's sportsblad) og Chr. I. P. Vel det tætteste datiden var på en sponsorkontrakt, som skulle dække denne idrætsmands rejseomkostninger. Aftalen dementeres dog senere. En ukoordineret kommunikationsbrist, der kunne resultere i afslutning på denne berømte cykelridders amatørkarrie- 
re. Interessen for deltagelse dalede også pga. tidspunktet for afviklingen, hvor danske cykelriddere endnu ikke havde påbegyndt træningen, og som angivet i Cyclisten ville sydeuropæere kunne møde bedre forberedt. Den eneste repræsentative idrætsorganisation De danske Skytteforeninger har ikke modtaget nogen invitation. Ved gennemlæsning af forhandlingsprotokollerne fra denne tid, er de olympiske lege ikke nævnt. Muligheden foruden invitation til at tilmelde sig med baggrund $i$ avisartikler, må afvises som følge af IOC's krav om accept i Paris. Tilbage bliver muligheden af, at de føromtalte efterinvitationer er ankommet som carte blanche, og at de 3 olympianere har tilmeldt sig. Ingen af dem nævner dog i erindringsartikler, hvorledes de blev tilmeldt.

\section{Finansieringen af dansk deltagelse}

Dansk idræt var omkring århundredeskiftet privat og amatøridræt og derfor uden økonomiske midler. Det var derfor nødvendigt for, at en dansk deltagelse ved de olympiske legene kunne blive en realitet at indsamle penge via private.

Holger Nielsen postulerer, at han om sommeren 1895 i avisen erfarede, at der var planer om at sende delegerede til Athen, og han ville derfor prøve at indsamle penge til formålet. Han forelagde ideen for Eugen Schmidt, som ikke fandt den realistisk. Dagen efter opsøgte Holger Nielsen dog direktørerne i Magasin du Nord, der i parentes bemærket var ivrige sejlsportsfolk. Han overtalte dem til at yde et bidrag på $250 \mathrm{kr}$. Dette overbeviste Eugen Schmidt om det realistiske i muligheden af at samle et beløb til dansk deltagelse.
Bekendte til Eugen Schmidt blev derefter sat i gang med at overbevise flere velhavende danskere om vigtigheden af dansk deltagelse og det lykkes at indsamle 1200 $\mathrm{kr} .{ }^{15}$ Til sammenligning skal anføres, at en gymnasielærer med 3 års anciennitet fik en årsløn på $1850 \mathrm{kr}$. og en gymnastiklærer samme sted $1600 \mathrm{kr}$. for også at nævne, at kvindelige gymnasielærere oppebar 1500 kr. i årsløn med 3 år på bagen. ${ }^{16}$ Inspektørlønnen på Carlsberg var 3500 kr. årligt. ${ }^{17}$

Da Holger Nielsen den 1. april tog på »påskeferie « til Athen skulle han og de 2 andre atleter således bruge lidt mere end han selv tjente på et år. De sidste penge indløb få dage før afrejsen, som var fastsat til 1. april. Bladet Idrat oplyser den 27. marts 1896, at der nu »kun mangler et par hundrede kroner i indsamlingen $\kappa^{18}$ Derudover havde Holger Nielsen og Eugen Stahl indgået aftaler med to førende københavnske dagblade om at skrive artikler hjem under legene og derved få et ekstra bidrag til omkostningerne.

Efter mange beregninger og overvejelser nåede man frem til, at denne sum kunne finansiere rejse og ophold for 3 personer. En nyansat lærer, en ingeniørstuderende og en inspektør på Carlsberg har næppe været i stand til selv at betale meget.

Det viste sig imidlertid, at pengene ikke rakte til at finansiere hele turen og danskerne fra Athen måtte telegrafere til Eugen Schmidt's fader efter flere penge.

I Venedig på vej hjem slap pengene endeligt op, og de 3 danskere sultede derefter i 2 døgn til de nåede færgen mellem Tyskland og Danmark, hvor de på kredit fik et fad smørrebrød. ${ }^{19}$

En sådan situation vidner om, hvor idealistisk danskernes deltagelse i legene var, og at der ikke var den store nationale opbakning omkring deltagelsen. 


\section{Udpegning af danske sportsfolk}

I 1896 fandtes der ingen dansk udtagelseskomite, som kunne udpege den danske delegation. Dansk Idræts-Forbund blev dannet den 14. februar og var ikke gearet til OL-udtagelse på daværende tidspunkt. De, der tog initiativet, må formodes også at have haft de bedste kort på hånden. Det kan ligeledes formodes, at ikke enhver havde tid til at være væk fra arbejdet i så lang tid. I øvrigt var en kvalificeret dansk deltagerkreds begrænset til København, idet sporten endnu ikke havde væsentlige udøvere i provinsen. Man kan vel også formode, at den indsamlede beløbssum klart afstak rammen for antal deltagere.

De 3 personer som blev den danske delegation ved de første moderne olympiske lege var:

\section{Stud. polyt. Alexander Viggo Jensen:}

Han var aktiv idrætsmand i roning, atletik, skydning og vægtløftning. En af datidens stærke idrætsmænd.Senere civilingeniør, bosat i USA.

\section{Løjtnant og laerer Holger Louis Nielsen:}

Senere oberstløjtnant, Rektor for Statens Gymnastik Institut og idrætsinspektør i Gentofte kommune. Han var også selv aktiv idrætsmand og dyrkede roning, skydning, svømning og fodbold. Forfatter af det første skrevne regelsæt i håndbold.

\section{Inspektør Eugen Stahl Schmidt:}

Senere erhvervsdirektør i Jylland. Var meget aktiv idrætspolitisk og var med til at starte flere idrætsforeninger og organisere idrætsgrene herunder også medstifter af Dansk Idræts-Forbund. Han var bl.a. også aktiv i roning, gymnastik, tennis, fodbold, fægtning og skøjteløb.
Derudover har der i kilderne optrådt 3 personer som skulle have været på tale til eventuelt deltagelse.

På de lister, man kan rekvirere fra IOC's Documentation \& Research Services optræder en Henri Juncher Hoeg. ${ }^{20}$ Dette er en fejl. Han forekommer ikke i nogen anden kilde. Andetsteds forekommer en assistent C. Winkler ${ }^{21}$ som var en meget vindende diskoskaster i Handelsstandens Atletikklub; men han er ikke opført på ovenstående liste og heller ikke omtalt i beskrivelserne fra legene. Det kunne tænkes, at den personlige $\varnothing$ konomi havde sat begrænsningen.

Som før nævnt var det på tale, at den europæisk kendte cykelrytter Chr. Ingeman-Petersen skulle have repræsenteret Danmark. Chr Ingeman-Petersen meddeler senere, at der i hans cykelforretning i denne periode er så stor travlhed, at han ikke kan afse den fornødne tid. Manden havde verdensklasse. ${ }^{22}$ Måske har det spillet ind, at investeringen ikke stod mål med hans vinderchancer så tidligt på sæsonen.

På hvilket grundlag udvælgelsen af de endelige deltagere skete, er der i de forskellige kilder en vis uenighed om. Ifølge Holger Nielsen selv er han og Eugen Schmidt udtaget, fordi de skulle ned og

Se og lære, og at bringe så mange oplysninger om de fremmede deltageres opfattelse og udførelse af de forskellige idrætter med hjem. ${ }^{23}$

Ifølge tidsskriftet Idrcet er årsagen til, at netop disse personer skal afsted den, at de spænder over et bredt spektrum af idrætsgrene og dermed kan repræsentere Danmark i mange discipliner. Ifølge denne tekst skal det dog nævnes, at der her tales om fire deltagere hvor den fjerde er C. Winckler.

Dagbladet Politiken mener endvidere, at 
Valget af deltagerne gjaldt det derfor foruden at få dygtige all round atleter tillige at faa saadanne samlede, som var villige til selv at bidrage ret betydeligt til rejsen- og som tillige var i besiddelse af en del sprogfærdighed. ${ }^{24}$

De udpegede eller valgte var alle veluddannede og besad dermed nok også en vis sprogfærdighed. Desuden mener jeg ikke, det skal udelukkes, at Eugen Schmidt og Holger Nielsen var de personer, som udgjorde hovedkræfterne i indsamlingen til turen, og at man måske derfor fandt det rimeligt, at de derfor også skulle deltage.

Viggo Jensen var på det tidspunkt blandt de mest aktive vægtløftere herhjemme og har derfor en rimelig god bevæggrund for deltagelse i legene.

Det kan alligevel undre, at man vælger at sende kun en specialist og to generalister (observatører) afsted i stedet for at sende 2 specialister Winckler og Viggo Jensen og en observatør afsted. Holger Nielsen og Eugen Schmidt var begge gode roere; men roning blev sløjfet af programmet pga. omkostningerne med bådtransport.

\section{Sportsfolk-sportsgrene}

Ved de første olympiske lege var der 42 programsatte discipliner. Mange deltagere deltog i flere discipliner. Ikke overraskende majoriserede grækerne legene med et deltagertal på 135 ud af de 238 fremmødte. Danskernes muligheder for at ind- og tilpasse sig IOC's disciplinkatalog findes ved at lave et simpelt check af 2 markante idrætsfester i København med de første moderne lege. Her ses det, at der var et langt større antal idrætsgrene med til de olympiske lege, og at en del af de discipliner, som var programsat ved legene, var sportsgrene som eksempelvis vægtløftning og cykling og som alene kunne bære et stævne herhjemme. Træningen i cykelridt startede af vejrmæssige grunde først i april måned på de danske baner og veje, hvilket også er et af argumenterne for, at Clubben Cyclisten alligevel ikke syntes, at det var pengene værd at sende en dansk repræsentant til Athen.

Sporten i København var på daværende tidspunkt stadig så ung, at den endnu ikke havde nået at organisere sig, og dermed havde udøverne heller ikke den store erfaring $i$ at konkurrere $i$ visse sportsgrene som stangspring og kuglest $\varnothing d$.

\section{Discipliner med dansk deltagelse}

Alligevel deltog de 3 danskere i 13 ud af de 42 discipliner. Det var fra starten meningen, at primært Viggo Jensen skulle være den aktive medaljedeltager, mens Eugen Schmidt og Holger Nielsen kun deltog for at $1 æ r e .{ }^{25}$

Danskerne deltog i følgende discipliner (se næste side):

Ved de første moderne olympiske lege eksisterede der ikke guldmedaljer. Vinderen fik i stedet en sølvmedalje og en olivenkrans. Andenpladsen blev hædret med en lauerbærkrans og ikke en sølvmedalje og en tredieplads gav ikke bronze men blot en placering.

I Danmark blev vindere traditionelt hædret med en guldmedalje; men efter OL blev dette ændret, og gennem en årrække gav en førsteplads en sølvmedalje. ${ }^{26}$ Vægtløftning var den disciplin, hvor Danmark opnåede det bedste resultat, idet Viggo Jensen sejrede i 2-armsløft og opnåede en andenplads i 1-armsløft. Dette var den eneste disciplin, hvor Danmark stillede med en specialist.

I skydning opnåede Holger Nielsen en 


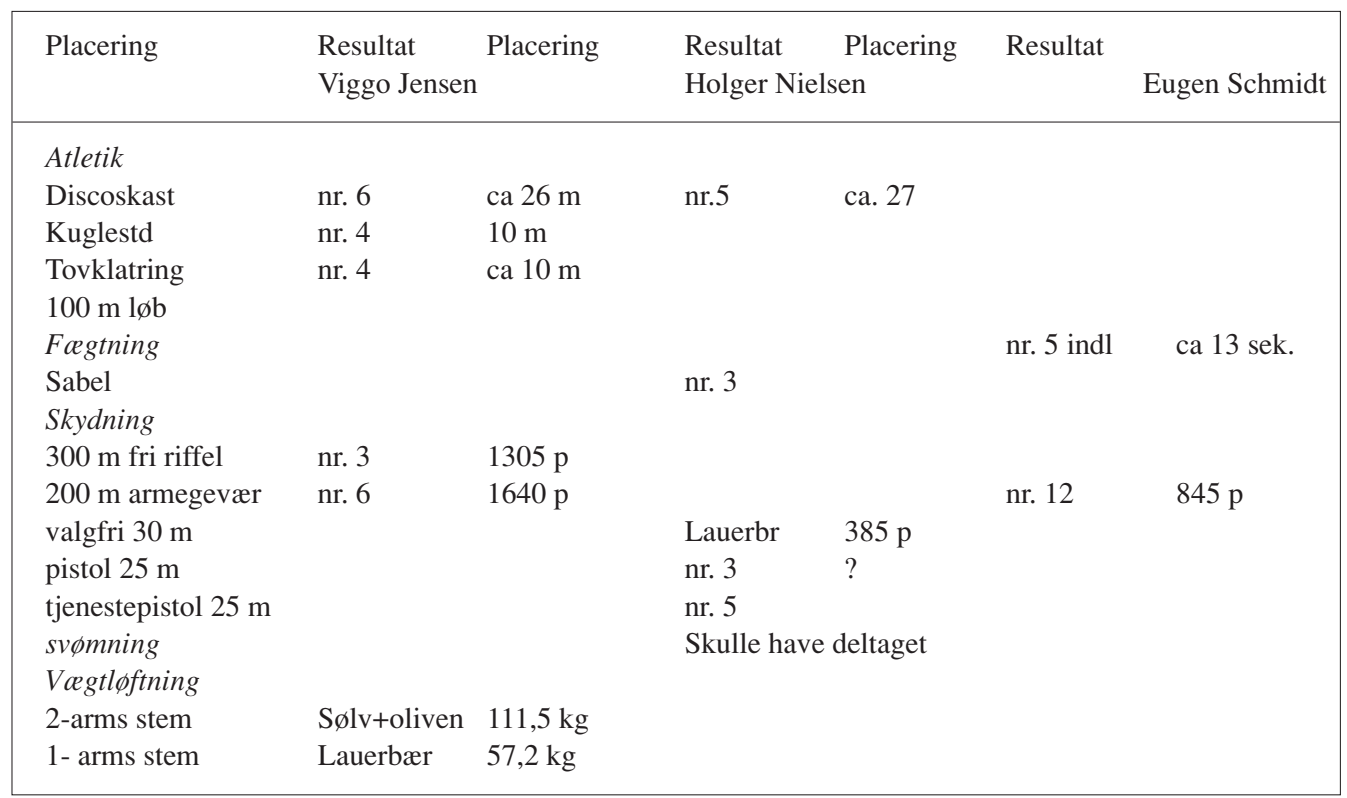

andenplads i valgfri $30 \mathrm{~m}$. pistol, hvilket bla. kan skyldes hans militære baggrund. Dernæst opnåede Holger Nielsen og Viggo Jensen begge en tredieplads i henholdsvis $25 \mathrm{~m}$. pistol og $300 \mathrm{~m}$. fri riffel. Holger Nielsen fik i endnu en militærdisciplin en tredieplads i sabel.

Eugen Schmidt deltog kun i 2 discipliner nemlig $100 \mathrm{~m}$ løb og $200 \mathrm{~m}$ riffel, men opnåede ikke en nævneværdig placering. Viggo Jensen, som var langt den mest aktive, deltog desuden i tovklatring, kugle og diskos og fik 2 fjerdepladser og en sjette plads.

Det kan udfra danskerenes baggrund for deltagelse konkluderes, at deres placeringer er rimelige $\mathrm{i}$ betragtning af, at de ikke var specielt velkvalificerede, bortset fra $\mathrm{i}$ vægtløftning.

\section{Den danske mediedakning}

Mange internationale aviser og nyhedsburauer som Le Figaro og Ritzau, Times, Illu- strations havde udsendt medarbejdere til legene.

Efter gennemlæsning af samtlige danske aviser i perioden 31. marts til 26. april 1896 har jeg fundet artikler om de olympiske lege $\mathrm{i}$ :

\section{Nationaltidende}

den 4., 7. og 8. april med

266 linier ialt $=2$ spalter

Kфbenhavn

den 9. april med

62 linier

Socialdemokraten

den 9. april med

10 linier ialt $=$ lille notits

\section{Politiken}

den 31. marts 8., 13., 14., 16., 17., 18. og 24. april med 816 linier ialt $=5,4$ spalter

Dannebrog ${ }^{27}$

den 8., 9., 11., 12., 13., 14., 15., 16., 17., 21., 23., 24. og

26. april med 2212 linier ialt $=14,74$ spalte 
Jyllandsposten nævner overhovedet ikke begivenheden.

De 5 først nævnte aviser er alle københavneraviser, hvor Jyllandsposten dengang var en lokalavis.

Sporten var et københavnerfænomen, og sportsomtale derfor også et københavnsk medieemne. Sport havde stort set ikke vundet indpas i provinsen, og dermed havde begivenheden heller ingen interesse for læserne. Ud af ovenstående ses, at størstedelen af mediedækningen blev foretaget af de to københavnske aviser, Dannebrog og Politiken. Disse to dagblade var rundet ud af samme avis, nemlig Morgenbladet. Morgenbladet var talerør for partiet Venstre. Dette dagblad fik med kredsen omkring brødrene Brandes en radikal europæisk drejning i et opgør med den kristlige-nationale romantik, men fik det i en grad, som ikke bekom grundtvigianeren og politikeren Berg vel. Den europæiske dimension gled ud af bladet og blev knyttet til dagbladet Politiken. Morgenbladet knyttede sig til de moderate venstre, men der var ringe grobund for disse i København. Politikeren Alberti overtog resterne og skabte dagbladet Dannebrog. ${ }^{28}$ Disse to aviser var således skarpe konkurrenter og brugte måske dette første internationale sportsstævne til at markedsføre sig på. Dannebrog for at fremhæve den danske nationalfølelse, og Politiken som en avis i det moderne kulturelle gennembrud for at vise sine læsere, hvad der skete i Europa. Sport var kultur og kultur over nationale grænser. Begge aviser havde nogenlunde samme oplagsstal på 12-14000.

Begge dagblade brugte unavngivne rapportere til legene. En bibliotekar fra dagbladet Politiken har i maj 1996 telefonisk oplyst, at bladets rapporter var Eugen Schmidt. Dannebrog bragte hver dag ofte flerspaltede artikler omhandlende legene. Korrenspondenten var forfatteren Holger Rosenberg. Til Dannebrogs artikler bidrog også Holger Nielsen. De to olympianere burde således i det skrevne være konkurrenter. Hvor stor en del af artiklerne Holger Nielsen skrev er svært at se, men efter hans eget udsagn var det ikke meget, idet han samtidig var aktiv deltager. Når både Holger Nielsen og Eugen Stahl Schmidt skriver anonymt i aviserne om deres bedrifter, kunne det tænkes, at de ikke ville i konflikt med de strenge amatørregler - de fik jo penge i kraft af deres sportsudøvelse og måske kunne Dansk Idræts-Forbund få et troværdighedsproblem herved. Men honorarerne var velkomne for at dække de store rejseomkostninger! De to unavngivne rapporteres valg af avis har vel været lidt tilfældigt; men det kan dog bemærkes, at militærmanden Holger Nielsen vælger den mest nationale af de to dagblade. De to sportsmænds politiske tilhørsforhold kendes ikke.

Politiken og Dannebrog dækkede begivenhederne forholdsvis ens. Den politiske forskel anes i de to dagblades artikler, hvor Dannebrog i større grad er optaget af kongehusets profilering og danskernes præstationer, mens Politiken ser præstationerne med baggrund i det internationale klima. Men materialet er dog for spinkelt til at kunne afdække det mere præcist. Dette må til dels skyldes, at de oplevede tingene sammen, og et vist samarbejde har de nok også haft. Dannebrog var blot mere detaljeret. De øvrige aviser har blot enkelte indlæg omhandlende legene. Fælles er, at de alle nævner åbningen af legene og Viggo Jensens sejr i vægtløftning.

Tidskriftet Idrat havde en del artikelskriveri omhandlende legene, inden disse påbegyndtes. Derfor er det lidt mærkeligt, at de under afholdelsen af legene kun 
bragte 2 meddelser. Den første var en lille notits på 2 linier med meddelsen om, at Viggo Jensen havde sejret i vægtløftning. Denne nyhed havde de fået via telegram fra Ritzau. Den anden var en enspaltet beretning om cykelløbene ved de olympiske lege, og her er ikke angivet kilde. ${ }^{29}$

\section{Danskere $i$ ilden}

De første moderne olympiske lege blev åbnet den 6. april 1896 på Pantheneum stadion i Athen. Allerede ved de første lege ville man gøre legene til noget storslået. Ved indvielsesceremonien deltog 80.000 tilskuere herunder den kongelige familie. Kongen bød velkommen, og der var til lejligheden komponeret en olympisk hymne.

I Dannebrog berettes om en euforisk stemning, som herskede i hele Athen, og om hvordan hele byen var klædt i festdragt.

Diskoskastning var programsat til den første dag, og heri deltog både Viggo Jensen og Holger Nielsen. Han havde selv medbragt en diskos som pga. af faconen blev kasseret af de græske dommere, og han fik tildelt en anden. Med denne kastede Holger Nielsen 4 meter kortere, end han under $\emptyset$ velserne havde gjort med sin egen tungere diskos og fik dermed ingen placering.

Konkurrencen blev vundet af en amerikaner, som aldrig tidligere havde kastet diskos. Dette viser hvor simpelt konkurrenceniveauet var. Der ikke blev stillet færdighedskrav til den enkelte deltager for at stille op i en disciplin. Eksemplet med diskos'en er ligeledes et tegn på det manglende regelsæt/standardisering af regler.

I sabelhugning deltog Holger Nielsen, hvor han som før nævnt fik en andenplads. Efter han i de indledende runder havde vun- det, mødte han i finalen en græker. I den sidste og afgørende omgang hugger de to næsten samtidig, og dommerpanelet kan ikke nå til enighed om, hvem der skal vinde. Holger Nielsen og hans modstander må tage en ny omgang og her sejrede grækeren. ${ }^{30}$

Dette er et yderligere bevis for, hvor upræcist regelsættet var.

I skydning var der programsat mange discipliner. Heri deltog Holger Nielsen bla i $30 \mathrm{~m}$. pistol skydning, hvor han kæmpede mod amerikaneren Payne. Selvom de var modstandere, hjalp Payne Holger Nielsen i skydekonkurrencen.

Dette imponerede Holger Nielsen meget og stod fremover for ham som det ypperste mål af fairplay og god sportsånd; noget han gennem resten af sin idrætskarriere forsøgte at efterleve. Paynes våben var af væsentlig nyere dato (hans fader var våbenfabrikant), og han ramte derfor også bedre. Efter matchen forærede han Holger Nielsen dette våben. ${ }^{31}$

Disse episoder, som blot er et udvalg, vidner om, hvor meget legene dengang adskiller sig fra dem, vi har idag, hvor simple de var, og at det ofte var tilfældigheder, der afgjorde konkurrencerne.

\section{Konklusion}

De første moderne olympiske lege var simple, mandsdominerede, private i finansieringen og organiseringen og meget europæiske.

I Danmark ses samme tendens med den spektakulære sport, som tager afsæt i industrialiseringens centrum. Sporten var bundet til ildsjæle, der privat og selvforvaltende griber tidsånden og fører den til praktisk idrætshandling. Det er ikke tilfældigt, at den organiserede foreningsidræt (sport) bygges op af de mænd, der støttede og repræsenterede Danmark i Athen. 
Den store mystik om de forsvundne invitationer har jeg fors $\emptyset \mathrm{gt}$ at afdække endnu et stykke, inden dette lille, men spændende, stykke idrætshistorie måske endeligt kan skrives.

\section{Noter}

1. Sven Turnberg, och S,E.Bring:: Världshistoria b. 13 Stockholm. 1934 s. $226 \mathrm{f}$

2. Vagn Dybdahl: Danmarks Historie bind. $12 \mathrm{Kbh}$ 1965 s. 33

3. Else Trangbæk: Den engelske sports gennembrud i Norden Viborg s. 164

4. Danmarks Olympiske Akademis informationsmappe; 1995 afsnit 5

5. Povl Engelstoft: Dansk Biografisk Leksikon b.11 s. 142 ; Kbh. 1983

6. Telefon oplysning fra LO personale arkiv

7. Christopher R. Hill: Olympics politics Manchester 1992 s 22-23

8. Lord Killanin: The Olympics Games London 1979, s. 14

9. P.C. Mc intoshLandmarks in the history of physical education London 1957. s130

10. Fotokopi vedlagt billede af invitationen

11. Evald Andersen \& Gunner Hansen Dansk idræt gennem 50 aar Kbh.1946 side 35. Danmarks Olympiske komite 75 års Jubilærumsskrift.

12. Preben Kristensen Ol-Bibliografi .1996; s. 2

13. Idræt tidskrift Kbh 1896 nr. 8 s. 118

14. Idræt tidskrift Kbh 1896 nr. 9 s. 132

15. Arne Rahbek: Portræt af en dansk idrætspioner, Holger Nielsen. Jelling 1990.

16. Meddelser fra Ordrup Latin og Realskole skoleåret 1895-96

\section{Litteratur}

Andersen, Evald og Hansen, Gunner: Dansk idræt gennem 50 aar. Standard Kbh.1946.

Carl-Diem- Institut: Publikation i Olympic Idea Fra Mandl, Simon Documentation \& Research Services Olympic museum. Lausanne fax fra den 25. Jan 1996.

Danmark Olympiske Akademi: Informationsmappe
Det har også kunnet konkluderes, at sportsbegivenheder internationalt kunne påråbe sig pressens interesse.

17. Arkivar Ulla Nymand, Carlsberg. telefonisk information

18. Idræt Tidskrift Kbh. 1896 nr. 13 s. 207

19. Holger Nielsen Dansk Idræts-Forbund- officielle meddelser H.G. minder fra dansk idrætsliv nr 1 januar 1946 s. 7

20. Wolf Lyberg: studie lavet for den internationale Olympiske komite.

21. Idræt - Vor Tids store Folkeopdrager, Odense s.312

22. idræt Tidsskrift Kbh. 1896 nr.1 s. 4;,nr.5 s. 69 og nr. 8. s. 118

23. Holger Nielsen Dansk idræts- Forbund- officielle meddelser Holger Nielsen minder nr $1 \mathrm{Kbh}$. jan 1946, s. 18

24. Politiken, avis den 14 april 1896 s. 2

25. Politiken Avis 14. april 1896. s. 2

26. Dannebrog, avis den. 23. april $1896 \mathrm{~s} .3$

27. Avisen Dannebrog eksisterede fra 1892-1910, hvor den blev afløst af avisen Riget

28. De danske aviser b. 2; s. 189 f \& 172

29. Idræt-tidssktift 17. april 1896 s. 249

30. Dannebrog Avis den16 april 1896. s. 2

31. Gunner Hansen og Vagn Hansen: Olympiadebogen de Olympiske lege 1896-1936 Kbh.1952 side 32-33

Om olympisme og de olympiske lege. Danmarks Idrætsforbund 1995.

Danmarks Olympiske komités 75 års Jubilæumsskrift.

Dannebrog: Avis den. 8, 9, 11, 12, 13, 14, 15, 16, 17, 21, 23, 24, 26. april 1896.

Dansk Sportstidende: Tidsskrift Kbh. Årgang 1894. 
Engelstoft, Povl: Dansk Biografisk Leksikon bind. 11 Schack-Siegumfeldt J.H. Schultz forlag København 1983.

Dansk Idræts-blad: blad Kbh. Årgang 1900.

Dybdahl, Vagn: Danmarks historie bind 12. Politikens forlag Kbh. 1965.

Hansen, Gunner: Olympiadebogen de olympiske lege 1896-1936 Samlerens forlag Kbh 1952.

Hill, Christopher R: Olympic Politics Mannchester University Press Manchester 1992.

Idræt: tidsskrift Kbh. Årgang 1896.

Jyllandsposten, Avis perioden den. 5-25 april 1896.

Killanin, Lord \& Rodda, John: The olympic Games Macdonald and Jane's Limited London 1979.

Kristensen, Preben: Danmark Olympiske Akademi: endnu upubliseret OL-biografi.

København: Avis den. 9. april 1896.

Lyberg, Wolf: study from the International Olympic Committee. Fra Mandl, Simon Documentation \& Research Services Olympic museum Lausanne fax 25 Jan 1996.
Mc intosh, P.C.mfl. Landmarks in the history of physical education. Routledge \& Kegan Poul. London 1957.

Meddelser fra Ordrup Latin og Realskole skoleåret 1895-1896.

Nationaltidende: Avis den. 4, 7, 8 april 1896.

Nielsen, Holger Oberstløjtnant Holger Nielsens minder Dansk idrætsforbund. Officielle meddelser nr 1. jan. Kbh. 1946.

Politiken: Avis den 31. marts, 8, 9, 13, 14, 16, 17, 18, 24 april 1896.

Rahbek, Arne: Portræt af en dansk idrætspioner Holger Nielsen On-side, Jelling 1990.

Socialdemokraten: Avis den. 9. april 1896.

Søllinge, Jette D. og Niels Thomsen: De danske aviser 1634 - 1989 b. 2, 1989, Odense Universitetsforlag.

Trangbæk, Else.: Den engelske sports gennembrud i Norden Olesen offset, Viborg.

Turnberg, Sven och S.E. Bring: Världshistoria, bind 13, Stockholm 1934. 